\title{
The Effect of Implementation English Material Technical Contained on Vocational Schools
}

\author{
Ahmad Nasihin ${ }^{1,2, *}$
}

\author{
${ }^{1}$ Education Doctoral Program, Bengkulu University, Indonesia \\ ${ }^{2}$ SMK Negeri 1 Empat Lawang, South Sumatra \\ *Corresponding author.Email: ahmad_nasihin21@yahoo.com
}

\begin{abstract}
Learning English at vocational high schools has been provided, but the motivation and skills of students are still very low so they are rejected for international scale industry. Therefore, it is necessary to practice English Learning Teaching (ELT) by innovative materials designed based job demands need on appropriate study program in vocational School. This study aims to find the impact of using ELT material designed by technical of engineering content or English Material Technical Engineering Content (EMTEC) in improving learning outcomes and motivation of English in Motorcycle Engineering and Business students. The research method is carried out by implementing English learning media with technical content on procedure text that is often used by vocational high school students in productive learning, known as job sheets of learning skills programs to 37 students by conducting pre and post tests as well as distributing questionnaires on perceptions and learning motivation of Vocational High School students for Motorcycle Engineering and Business competences. The results showed that the first EMTEC was effective in improving the English competency of the Motorcycle Engineering and Business students in using English with an average post-test rate of 68.00 with an increase of $26 \%$ compared to the pre-test score of 42.00. Second, the perceptions of students in beginning is negative to non-EMTEC with 22 $(59.46 \%)$ to general material or non-EMTEC can improve skill, $25(67.57 \%)$ feel not enjoyed, $26(70.26 \%)$ got difficulty in learning by general ELT material, $19(51.35 \%)$ feel boring and $18(48.65 \%)$ having lower motivation. The perception and motivation after EMTEC implementation, participants show positive statements with $22(59.49 \%)$ agree EMTEC can be increased interest and motivation, $27(72.97 \%)$ felt enjoy in ELT, 30 (81.01\%) got clear and easier in ELT, 23 (62.16\%) did not feel boring in learning English by EMTEC, and 26 (70.27\%) got improvement skill and motivation by EMTEC. Participants believed that EMTEC is important to support their future in work field. It is suggested to university and school to modify for students based their future need specifically.
\end{abstract}

Keywords: Implementation, EMTEC, Vocational High School, ELT, Engineering and motorcycle business program.

\section{INTRODUCTION}

Many problems in the form of not linking and matching SMK graduates with the challenges of English competency in the industrial world. According to Chen, in Taiwan, the purpose of organizing a Vocational High School (SMK) is to prepare students to integrate knowledge and practical skills that are in accordance with their fields of expertise with careers in the workforce [1].

According to Tomlimson said that material on learning and teaching must be predicted, it will work or not to the purpose or goal of learning and teaching [2]. Safnil also said that effective English learning material is based on the condition and needs of students as learners [3]. So it can be concluded that a media or tool can be said to be useful or effective if it works to produce a product and helps the object that is targeted to be better. Vocational High School English learning media provided by the government has not been able to answer the needs of students in preparing to face the challenges of competition in the world of work. Prachanant [4], Pinelopi [5], and Li [6] in their research on the use of language in the tourism industry, can better explore students' speaking ability. This shows that learning media with special content in special classes is more positive in developing students' English skills.

The same material for different majors will certainly affect student learning motivation. Ramazani shows that the teacher's perception of the concept of teaching materials is influenced by the demand for student exams [7]. Richards, JC also said that curriculum development is very important to do regularly based the field needs [8]. Too general target of national exams makes vocational students and teachers forget about the challenges of the world of work in speaking English.

From the above background, it can be seen that it is important and urgent to develop learning media connected to international standard agreements in the Asean Economic Community (MEA). 


\section{LITERATURE REVIEW}

Learning curriculum and learning material for purpose is to increase motivation and skill of students. Some researches about this are conducted by researches such as Prachanant [4], Pinelopi [5], and Li [6] in their research on the use of language in the tourism industry, can better explore students' speaking ability. Others group of studies such as conducted by Ahmed, MK [9], Al-khatib, MA [10], Baghban, ZZ, \& Ambigapathy, P. [11], Basturkment, H. [12], Dja'far, VH, Cahyono, BY, \& Bashtomi, Y. [13], Esteban, SG, \& Martínez, CT [14], Fiorito, L. [15].

Tomlimson [2] said that material on learning and teaching must be predicted, it will work or not to the purpose or goal of learning and teaching. Safnil [3] also study that effective English learning material is based on the condition and needs of students as learners. Brown, HD also says something can be said to be effective if it is given appropriate results / products and object satisfaction [16]. Leong, $\mathrm{AM}, \& \mathrm{Li}, \mathrm{J}$. stated that strategy in teaching is very important and it is needed to optimized [17]. Qin, M. also found that by effective ESP students of tourism class skills can be improved [18]. So, strategy to design or developed suitable materials for learning and teaching activity is very crucial step before come to the class room.

Specific English Material for ELT is recommended by many linguistics experts such as Zahedpisheh, N., Abu, ZB, \& Saffari, N. [19], Hutchinson \& Waters [20] and Kitkauskienè [21], who conducted research about using English for Specific Purpose (ESP) at university and vocational schools/ vocational class. ESP can become one of solution for the lowe motivation in learning English. As finding study done by Chen [1]; and Masofeedah, Z., \& Tahririan [22]; and Chen \& Li, [23]; Chen, [1]; Liu [24] and Liu, W., Wu, C., \& Huang, Y [25] about the role of existence of a curriculum to improve students' abilities after learning.

The same learning materials for all majors also contribute to the problem of students' low competency in English. Socially, the people will be more interest to the specific thing near or friendly with them, as Bodenhausen and Hugenberg [26] discuss about social perception to the language. As Pham \& Malvetti [27] also the discussed about ESP in specific class is effective. So, the research problem can be formulated as follows: first, how is the effect of using ELT material designed by technical of engineering content (EMTEC) on the competency of technical and motorcycle business program? Second, how is students' perceptions of before using ELT material designed by technical of engineering content (EMTEC)? And third, how is student motivation after learning by using ELT material designed by technical of engineering content (EMTEC)?

\section{RESEARCH METHODS}

Following Gall, Meredith, D., Gall, Joyce, P., \& Borg, Walter, R. [28]. This research was conducted as education research at the Vocational High School (SMK) competency in Motorcycle Engineering by involving the semester 4 students consisting of 37 male students. During the study students were given pre-test on a learning and teaching, then the treatment given by ELT material designed by technical of engineering content (EMTEC) in learning and teaching English. The materials provided include: procedure text with a focus on automotive parts/ equipment, materials used in automotive work and work steps in automotive work.

The data of the effect of the implementation of ELT material designed by technical of engineering content (EMTEC) were carried out by pre-test and post-test. While students' perceptions and motivation carried out with a perception questionnaire of the use of English teaching materials, procedures with technical content in English learning.

\section{RESULTS AND DISCUSSION}

\subsection{The improvement skill of students after following learning by using ELT material designed by technical of engineering content (EMTEC)}

To find out answer of first question from this research, it is conducted pre-test and post-test. The result of research as in table 1 below:

Table 1. The improvement skill of students after folowing learning by using ELT material designed by technical of engineering content (EMTEC)

\begin{tabular}{|l|c|c|c|}
\hline \multicolumn{1}{|c|}{ Part of Procedure text in evaluation } & Average Pretest & Average Posttest & Increase \\
\hline Stating the topic of procedure text & 45 & 65 & 20 \\
\hline Stating tool uses in doing procedure text & 47 & 70 & 23 \\
\hline Stating the ingredient of procedure text & 40 & 64 & 24 \\
\hline Stating the steps of procedure text & 43 & 73 & 37 \\
\hline amount & 175 & 272 & 104 \\
\hline \multicolumn{1}{|c|}{ Average } & $\mathbf{4 3 , 7 3}$ & $\mathbf{6 8 . 0 0}$ & $\mathbf{2 6 . 0 0}$ \\
\hline
\end{tabular}


From the research results above, it can be seen that ability of students increased 20 points from the learning score before the use of the media. The competence of mentioning detailed information in the form of tools in performing a procedure also showed an increase of 23 points. For the competence to identify the materials needed to do something on the job sheet, it is also increased by 24 points after treatment using engineering or technical content material. The ability to inform the steps to do something in the text presented had the most significant increase, namely 37 points. The increasing of skill can be seen in the comparison of the pre-test and post-test of the students in the learning trial class, namely pre-test 43,73 in average of procedures text skills and post-test 68.00 with a gap increasing is 26.00 .

\subsection{Students' perceptions in of implementing ELT material designed by technical of engineering content (EMTEC)}

To find out the answer of second questions from this research, it is conducted questionnaires to students at before ELT process by using ELT material designed by technical of engineering content (EMTEC). The result of research as in below:

Table 2. Students' perceptions in beginning of implementing ELT material designed by technical of engineering content (EMTEC)

\begin{tabular}{|l|c|c|c|c|c|c|c|}
\hline \multicolumn{1}{|c|}{ ITEMS } & $\begin{array}{c}\text { Frequency } \\
(\mathbf{F}) / \text { Percent } \\
(\mathbf{P})\end{array}$ & $\begin{array}{c}\text { Strongl } \\
\mathbf{y} \\
\text { disagree }\end{array}$ & $\begin{array}{c}\text { Disgre } \\
\mathbf{e}\end{array}$ & $\begin{array}{c}\text { Not } \\
\text { Sure }\end{array}$ & Agree & $\begin{array}{c}\text { Strongly } \\
\text { Agree }\end{array}$ & Total \\
\hline $\begin{array}{l}\text { Q-1) English teaching materials } \\
\text { in general Hand book increased } \\
\text { my interest in learning }\end{array}$ & $\mathrm{F}(0-37)$ & 10 & 22 & 2 & 2 & 1 & 37 \\
\cline { 2 - 10 } & $\mathrm{P}(0-100 \%)$ & 27,03 & 59,46 & 5,41 & 5,41 & 2,70 & 100 \\
\hline $\begin{array}{l}\text { Q-2) English teaching materials } \\
\text { with General contents enjoy } \\
\text { being followed }\end{array}$ & $\mathrm{F}(0-37)$ & 6 & 25 & 2 & 2 & 2 & 37 \\
\cline { 2 - 10 } & $\mathrm{P}(0-100 \%)$ & 16,22 & 67,57 & 5,41 & 5,41 & 5,41 & 100 \\
\hline $\begin{array}{l}\text { Q-3) The General content of } \\
\text { English teaching materials is not } \\
\text { difficult }\end{array}$ & $\mathrm{F}(0-37)$ & 8 & 26 & 1 & 1 & 1 & 37 \\
\cline { 2 - 9 } & $\mathrm{P}(0-100 \%)$ & 21,62 & 70,27 & 2,70 & 2,70 & 2,70 & 100 \\
\hline $\begin{array}{l}\text { Q-4) English teaching aterials } \\
\text { with general contents are not } \\
\text { boring }\end{array}$ & $\mathrm{F}(0-37)$ & 19 & 15 & 1 & 1 & 1 & 37 \\
\cline { 2 - 9 } & $\mathrm{P}(0-100 \%)$ & 51,35 & 40,54 & 2,70 & 2,70 & 2,70 & 100 \\
\hline $\begin{array}{l}\text { Q-5) English teaching materials } \\
\text { with general content increased } \\
\text { my motivation and skills in } \\
\text { English towards the world of } \\
\text { work }\end{array}$ & $\mathrm{F}(0-37)$ & 12 & 18 & 2 & 3 & 2 & 37 \\
\cline { 2 - 8 } & $\mathrm{P}(0-100 \%)$ & 32,43 & 48,65 & 5,41 & 8,11 & 5,41 & 100 \\
\hline
\end{tabular}

The findings above show that for question 1 (Q-1) of item, the majority responses were 22 $(59,46 \%)$ participants disagree that English teaching materials in general Hand book increased interest or motivation in learning English. For item (Q-2) the majority responses were $25(67,57 \%)$ of state that English teaching materials with General contents enjoy being followed. Then for item (Q-3) the majority respondent $26(70,27 \%)$ stated disagree that the general content of English teaching materials is not difficult. Next finding, the item (Q-4) can be seen that $19(51,35 \%)$ strongly disagree that English teaching materials with general contents are not boring. The last, the finding show that majority responses $18(48,65 \%)$ stated disagree that English teaching materials with general content increased my motivation and skills in English towards the world of work
Then, from interview, it can be seen such as Debby said: "learning English with common materials such as about computers, about using rice cooker are not interesting and not for me because I do not so close to the items (interview: 20 January 2019). Aska also said: English is boring and not enjoy to follow because materials such as computer using steps is confused to be understood (Interview: January 2020). Inka also said: I feel my skill of English is not improved especially in procedures text because the topic is not recognized (Interview: January 2019). The data from interview can be seen that the students feel difficult, boring, unfamiliar, and not ELT by using general ELT material from national hand book. 


\subsection{Students' perceptions after implementing ELT material designed by technical of engineering content (EMTEC)}

To find out answer of third questions from this research, it is conducted to students after ELT process by using ELT material designed by technical of engineering content (EMTEC). The result of research as in table 3 below:

Table 3. Students' perceptions after implementing ELT materials designed by technical or engineering content

\begin{tabular}{|l|c|c|c|c|c|c|c|}
\hline \multicolumn{1}{|c|}{ ITEMS } & $\begin{array}{c}\text { Frequency } \\
(\mathbf{F}) / \text { Percent } \\
(\mathbf{P})\end{array}$ & $\begin{array}{c}\text { Strongly } \\
\text { disagree }\end{array}$ & $\begin{array}{c}\text { Disg } \\
\text { ree }\end{array}$ & $\begin{array}{c}\text { Not } \\
\text { Sure }\end{array}$ & Agree & $\begin{array}{c}\text { Strongly } \\
\text { Agree }\end{array}$ & Total \\
\hline $\begin{array}{l}\text { (Q-6) EMTEC increased my } \\
\text { interest in learning }\end{array}$ & $\mathrm{F}(0-37)$ & 3 & 3 & 1 & 22 & 8 & 37 \\
\cline { 2 - 9 } & $\mathrm{P}(0-100 \%)$ & 8,11 & 8,11 & 2,70 & 59,46 & 21,62 & 100 \\
\hline \multirow{2}{*}{ Q-7) EMTEC is not confusing } & $\mathrm{F}(0-37)$ & 2 & 1 & 1 & 30 & 3 & 37 \\
\cline { 2 - 8 } & $\mathrm{P}(0-100 \%)$ & 5,41 & 2,70 & 2,70 & 81,08 & 8,11 & 100 \\
\hline (Q-8) EMTEs are not boring & $\mathrm{F}(0-37)$ & 1 & 1 & 2 & 23 & 10 & 37 \\
\cline { 2 - 8 } & $\mathrm{P}(0-100 \%)$ & 2,70 & 2,70 & 5,41 & 62,16 & 27,03 & 100 \\
\hline
\end{tabular}

The findings above show that for question 6 (Q-6) of item, the majority responses were 22 $(59,46 \%)$ participants agree that English teaching materials with technical content increased interest or motivation in . For item (Q-7) the majority responses were $27(72,97 \%)$ of students stated agree that English teaching materials with technical content enjoy being followed. Then for item $(\mathrm{Q}-8)$ the majority respondent $30(81,08 \%)$ stated agree that the technical or engineering content of English teaching materials is not confusing to be understood. Next finding, the item (Q-9) can be seen that $23(62,16 \%)$ agree that ELT material designed by technical of engineering content (EMTEC) are not boring to be followed. The last, the finding show that majority responses $26(70,27 \%)$ stated agree that ELT material designed by technical of engineering content (EMTEC) increased motivation and skills in English towards the world of work.

From interview it can be seen that student Dery said: learning English by automotive picture and kinds of mechanical steps ini motorcycle scoop is very interesting and useful for me because it can be implemented in my works (interview: 17 May 2019). The other group of as Tobing said: if material or text of English lesson consist of motor cycle part and kind of terms related to automotive, I feel enjoy and they are easier to be understood (Interview: July 2020). The data from interview can be seen that the students feel easier, and enjoyable, ELT by using EMTEC.

From the results of the above research, it can be explained that first, the results of the study show that the competence of Vocational High School students in English increases with EMTEC. This finding in line as Tomlinson said that something is said to be effective if it to reach the purposed objectives [2]. As safnil [3] also said that the effective learning material is designed based neeed so they can improve skills after learning. The finding also with the researches were conducted by Zahedpisheh, N., Abu, ZB, \& Saffari, N. [19], Hutchinson, T., \& Waters, A. [20] and Kitkauskienè, L. [21], Chen [1]; and Masofeedah, Z., \& Tahririan [22]; Chen \& Li, [23]; and Pham, HL, \& Malvetti, A. [28] They found that ESP materials in ELT can solve the problem of lowe skill and motivation of students in certain program on school and university.

Second, the findings about students' perceptions of the use EMTEC showed that students strongly agreed with the positive perceptions that students felt to learn English using EMTEC in the SMK. This is in line with the opinion from Chen that the learning material is not appropriate, and and the learning objectives and educational goals are not aligned with students' desire to learn English [1]. English material that displays lots of pictures, terms and text content related to Motorcycle Engineering is able to provide positive responses and interest in motorcycle engineering students at Vocational High Schools to Learn English. This perception is normal based on Bodenhausen, G. V, \& Hugenberg, $\mathrm{K}$ and Pham where they study about the basic human interaction [26, 27]. They research found that human will be motivated to communicate based their needs. So, motorcycle technics students were interested in EMCT more than general English materials.

Third, the EMTEC proved to be effective in increasing the motivation of vocational high school students. It is supported to previouse researches on learning English specifically defined as "target-oriented learning" as Hutchinson \& Waters [20]. Then Qin, M states 
that specific or specific content of learning English can effectively increase motivation to learn English [18]. This is in line with the results of this study that the motivation of vocational high school students in the motorcycle engineering and business program increases with the implementation of learning with technical content media (technical English content).

\section{CONCLUSION}

The first, implementation of EMTEC had improved skill in using English in procedures text or manual book for technical motorcycle students in vocational school. The skill which is improved is in determining the topic of reading text about the procedure for doing something.

Second, EMTEC is better that general English material as in books from educational and culture ministry of Indonesia. Students of vocational school more over from technical motorcycle are not interested to general materials which are not closely related to their program.

Finally, the third, EMTEC is effective to improve student's motivation and interest to learn English. Their motivation is improved because this ELT material is close to their work in technical program, easier to understand, and useful for supporting their work and career after graduating from vocational school.

\section{ACKNOWLEDGMENTS}

The author acknowledges the head master of SMK Negeri 1 Empat Lawang who allowed carrying out this research.

\section{REFERENCES}

[1] Chen, Z. M., \& Wang, L. F. (2009). Developing National Curriculum for BA Programs in Business English in China. Foreign Language in China, 6(4), 4-11, 21

[2] Tomlinsom, B. 2011. Materials Developement in Language Teaching. USA: Cambidge University

[3] Safnil. 2018. English Material Learning Development. Lecturer Material for Doctoral Program. Bengkulu: UNIB.

[4] Prachanant, N. (2012). Needs Analysis on English Language Use in Tourism Industry. Procedia - Social and Behavioral Sciences, $66,17-$ 125. https://doi.org/10.1016/j.sbspro.2012.1 1.253.

[5] Pinelopi, P. (2015). English for Specific Purposes: How to Teach English for Tourism. International Journals of English Literature and Culture, 3 (August), 235238. https://doi.org/10.14662/IJELC2015.06 9

[6] Li, J. (2016). Analysis of application for situational teaching method in tourism
English teaching. SHS Web on Conferences, (25), 1-5.

[7] Ramazani, M. (2013). Teachers' Perceptions of Using English Textbooks for Iranian Technical and Vocational College Students. Procedia - Social and Behavioral Sciences, $\quad 70, \quad 1748-$ 1762. https://doi.org/10.1016/j.sbspro.2013. 01.250

[8] Richards, JC (2001). Curriculum Development in Language Teaching. Cambridge University Press. https://doi.org/10.1111/j.15404781.20 07.00543_2.x

[9] Ahmed, MK (2014). The ESP Teacher: Issues, Tasks and Challenges. English for Specific Purposes World, 15 (42), 1-33.

[10] Al-khatib, MA (2005). English in the Workplace: An Analysis of the Communication Needs of Tourism and Banking Personnel. Asian EFL Journal, 7 (2).

[11] Baghban, ZZ, \& Ambigapathy, P. (2011). A Review on the Effectiveness of Using Authentic Materials in ESP Courses. English for Specific Purposes World, 10 (31), 1-14.

[12] Basturkment, H. (2010). Developing Courses in English for Specific Purposes. UK: Palgrave Macmillan.

[13] Dja'far, VH, Cahyono, BY, \& Bashtomi, (2016). EFL Teachers 'Perception of University Students' Motivation and ESP Learning Achievement. Journal of Education and Practice, 7 (14), 28-37.

[14] Esteban, SG, \& Martínez, CT (2014). Critical Reflections on Teaching ESP through Constructivist, Communicative and Collaborative Technological Integrated Procedures. Procedia - Social and Behavioral Sciences, 141, 342346. https://doi.org/10.1016/j.sbspro.2014.0 5.059

[15] Fiorito, L. (2005). Teaching English for Specific Purposes. Retrieved from https://www.usingenglish.com/articles/ teaching-english-for-specificpurposesesp.html

[16] Brown, HD (2000). Principles of Language Learning and Teaching. Englewood Cliffs, NJ: Prentice Hall Regents.Upper Saddle River, New Jersey.

[17] Leong, AM, \& Li, J. (2011). Optimization Strategies in English Teaching for Tourism Management Majors: a Case Study of Macau University of Science and Technology. International Journal of Arts \& Science, 4 (21), 315-328.

[18] Qin, M. (2013). Strategies for Improving Tourism English Teaching. Journal of Landscape Research, 5 (5), 43-44. 
[19] Zahedpisheh, N., Abu, ZB, \& Saffari, N. (2017). English for Tourism and Hospitality Purposes (ETP). English Language Teaching, $\quad 10 \quad$ (9), 94. https://doi.org/10.5539/elt.v10n9p86

[20] Hutchinson, T., \& Waters, A. (1992). English for Specific Purposes: A Learning Centered Approach. Cambridge: Cambridge University Press. https://doi.org/10.1016/S08894906(01)00047-3

[21] Kitkauskienè, L. (2006). General English and English for Specific Purposes (Esp). Santalka. Filologija, Edukologija, 14 (2), 88-92.

[22] Masofeedah, Z., \& Tahririan, MH (2013). Target Situation Needs Analysis of Hotel Receptionists. English for Specific Purposes World, 14 (40), 1-19.

[23] Chen, H. B. (2007). The Emphasis of Intercultural Information in Business English
Practical Teaching. Science and Technology, 36, 214, 256.

[24] Liu, W., Wu, C., \& Huang, Y. (2013). English for Specific Purposes (ESP) for Hospitality College Students and Hotel Employees in Taiwan. International Journal of Education and Research, 1 (8), 1-14.

[25] Bodenhausen, G. V, \& Hugenberg, K. (2009). Attention, Perception, and Social Cognition. Social Cognition: The Basis of Human Interaction, 1 (23), 1-22.

[26] Pham, HL, \& Malvetti, A. (2012). Teacher Perceptions of Teaching English for Specific Purposes (ESP) Programs: A Qualitative Study of Problems and Facilitative Strategies. Journal of Teaching and Education, 1 (3), 129-142.

[27] Gall, Meredith, D., Gall, Joyce, P., \& Borg, Walter, R. (2003). Educational Research: An Introduction (7th ed.). USA: Pearson. 